\title{
Narrative and Explanation: Explaining Anna Karenina in the Light of Its Epigraph
}

Published in Contagion: Journal of Violence, Mimesis, and Culture 11 (Spring 2004): 124-145

and in Imitazione creativa: Evoluzione e paradossi del desiderio. Ed. Raffaella Trigona. Bergamo: Moretti \& Vitali, 2004 (in Italian).

In this article, I will be examining the relation of explanation to narrative, looking briefly at the theoretical side of the problematic and in more detail at specific explanatory issues that arise in Tolstoy's novel Anna Karenina. Although the use itself of the term "explanation" is not as visible in the humanities as it is in the sciences, the explanatory enterprise by other names is just as prominent. For indeed, an animating impetus behind textual interpretation is an explanation of how a text can be brought into a correspondence with another text, while contemporary critical-theoretical activities of demystifying aesthetic and cultural assumptions, contextualizing historical knowledge, or laying bare ideological presuppositions are, in one way or another, engagements in the explanation of the workings of language. I approach humanistic explanation via a brief detour of scientific explanation, which constitutes an already established discourse with a set of defined issues and standard arguments, limiting myself to touching upon issues relevant to the narrativization of explanation.

I wrote in great detail on scientific explanation in Chapter I. Here I will give a brief recapitulation of the points relevant to my literary argument. In scientific debates, explanation is defined as an answer to the question of "why?", in contradistinction to the question of "what?", which prompts a description of a phenomenon in question. Descriptive and explanatory conceptual frameworks, however, are interdependent. A physical description involves an "in-depth" understanding of underlying regularities. An 
explanatory answer to a question is, in its turn, an argument that logically deduces the explanandum (the description of a phenomenon to be explained) from the explanans (well-understood regularities). This formal definition of an explanation necessitates a symmetry between explanation and prediction, because the reconstructed logical sequence can also be read in the other direction, demonstrating the inevitability of what has occurred. Thus the sight of shattered glass and a baseball lying about allows me to explain the accident by invoking the law of the conservation of momentum and the low shock-resistance of glass. But the knowledge of these regularities would have also allowed me to predict the same outcome had I seen the baseball flying in its direction of the window.

The ontological status of "regularities" has elicited a lively debate in the scientific community pertaining to the problem of the "real." The standard view of regularities defines them as general laws (the kind we learn about in physics classes) that could be deductive or inductive, deterministic or statistical. A general law may be subsumed under another, even more general law, thus forming a unifying hierarchy of laws. A rival conception appeals to causal mechanisms and defines regularities as established chains of temporal succession. Both models, the covering-law and the causal one, have been criticized: the former - for its failure to distinguish a law from an accidental generalization; the latter - for its resurrection of the metaphysical notion of causal influence and its inability to deal with probabilistic events. One of the later contenders is Nancy Cartwright's model, that proposes to conceive of regularities as so-called "nomological machines" - "fixed (enough) arrangement[s] of components, or factors, with stable (enough) capacities that in the right sort of stable (enough) environment will, 
with repeated operation, give rise to the kind of regular behavior that we represent in our scientific laws" (TDW 50). Cartwright claims that scientific models work on the ceteris paribus (everything else being equal) basis. That is to say they "hold only in circumscribed conditions or so long as no factors relevant to the effect besides those specified occur" (TDW 28), such as inside a battery, refrigerator, or a rocket - insofar as special shielding conditions are in effect (as a counterexample, imagine using Newton's laws of mechanics for describing the motion of a dropped crumpled dollar). Cartwright's explanatory framework is thus pragmatic and local, avoiding the twin pitfalls of the metaphysical assumptions underlying the two older models - the totalizing and unifying idea of a covering law, on the one hand, and the influence of causal "force," on the other. What is instead emphasized by her is the procedural aspect of scientific knowledge that has been historically prevalent and reflects the practical exigencies of human existence the experience of dangers and natural obstacles to human desires. When ill-defined impediments are analyzed and reduced to concrete difficulties, specific working procedures in the form of nomological machines can be offered to overcome them.

In Cartwright's model, the explanation of a phenomenon merges with the description of how to build a nomological machine. Hers is a powerful model that can account not only for deterministic phenomena but also for stochastic ones, described by statistical regularities. There remains, however, one class of phenomena not assimilable to this and other regularity models - singular, emergent phenomena, i.e. phenomena that can be described as principally novel or unexpected, because their occurrence cannot be predicted based on the available information: they can neither be logically inferred from the immediately preceding state of the system nor surmised from the consideration of its 
constitutive parts. These types are phenomena are covered by so-called genetic explanations. A genetic explanation "that consists in telling a story leading up to the event to be described" (SE 32) is invoked in the evolutionary theory, cosmology, geology, and history, among other disciplines. Although genetic explanations are highly problematic from the standpoint of philosophy of science, my objective in bringing them up is to point out the connection between a genetic explanation and narrative. In offering a genetic explanation, one tells a narrative of how something came to pass, such as a story of Darwinian selection. In a literary narrative, the narration of a singular or exceptional event, such as a story of transgression, functions similarly to a genetic explanation in that when our knowledge about the world cannot be regularized or proceduralized, we resort to telling stories.

The controversiality of genetic explanation, which has to do with its looseness and inability to yield predictions, arises partly because of what is left unexamined by philosophy of science, namely the "why-question" itself. Genetic argumentation, it seems to me, provides us with the paradigm for the why-question that can afford important insights into what constitutes the "explanatoriness" of explanation. I claimed earlier that "why" is the question of existential anxiety, which ties directly into what Martin Heidegger deems as the first question of metaphysics: "why is there something rather than nothing?" To this I would also add (because I believe they are the same types of questions): "why are there many things rather than one?"; "why is there this thing rather than some other?" - questions that can properly be addressed by telling a story of origin and the province of the earliest narratives: myths, legends, fairy tales. Even the whyquestions of the more pragmatic nature, as those asked in science, are derivative with 
respect to the "why something exists" question, for they also resonate with a sense of wonderment both at the givenness of existence (that something exists rather than nothing), as well as the variety, singularity, intricacy, and arbitrariness of nature and life forms. If this were not so, there would be no whys but simply pragmatic prompts for description. It is not that mythological and fairy-tale narratives explain the existential question of "why?", but rather, as I argued before, that unfolded responses to whyquestions are themselves anthropologically coextensive with narratives. This suggests that there is no grounding for the first, primordial "why?", because the why-question is itself internal to narrative structure, or, as I put it earlier "it is 'because' we have language, 'because' we have narrative, we ask 'why." In Chapter II I looked at SheetsJohnstone's and Gärdenfors's theories of the emergence of detached representation and at the contradictory understanding of freedom engendered by the gap of representation. I find it highly plausible that narrative structures project, in anthropological and kinesthetic terms, our physical alienation from the world and a resulting sense of impotence. Representation opens up the notion of transcendence that makes us conscious and anxious about objects that "slip out" of our hands and our limited ability of manipulating them. It could be said both that representation reflects this separation anxiety, as well as that this separation anxiety is epiphenomenal to representation itself. Therefore, the object of my analysis is not establishing the foundation of causation and explanation but exploring connections between the formal structures of representation and the anthropological-phenomenological structures of causal exigencies. Theorizing narrative as the paradigm of explanation would involve embedding it into a structure of significance that would be broader than a theory of conceptualization or a theory of 
context, but would involve an anthropologically-grounded understanding of narrative as a desire of human beings to understand themselves as maximally free, to use representation to heal the trauma of alienation that it has itself engendered, by creating stories of themselves as competent agents ready to face off what Hans Blumenberg in his Work on Myth calls "absolutism of reality," denoting man's lack of control over the outside world, which is experienced by him as an environment hostile and impervious to his needs and resistant to his exertions to transform it.

In light of these preliminary comments, I propose to approach the reading of Anna Karenina as an explanatory enterprise spurred by two prompts: the epigraph and the first sentence of the novel. I will put off the discussion of the epigraph ("Vengeance is mine; I will repay") until later and will start with the first sentence, which, according to the critical lore, was re-written by Tolstoy one hundred times. It reads: “All happy families resemble one another, each unhappy family is unhappy in its own way." Recast as an explanatory cue, it gives rise to questions, such as "why is it that some families are happy while others are unhappy?" and "why happy families are similar, while unhappy ones are dissimilar?" One could read these "whys" existentially, in the sense of "Look at all the different kinds of families that exist. Some are happy, while others are not.” But one could also notice that it resonates in a suggestive way with Cartwright's notion of the nomological machine by encoding proceduralized knowledge bound to generate predictable results. A happy family, namely, can be seen as a nomological machine, because, just like well-oiled and correctly functioning machines, "all happy families" function similarly, achieving the desirable state of "resembling one another." The 
workings of an unhappy family, on the other hand, are sadly out of tune with the proper running regime - and that is why it "is unhappy in its own way."

If the novel, as I claim, illuminates its first sentence, then we could expect it to present us with the paradigms of happy and unhappy families. Indeed, according to several sources, Tolstoy is said to have remarked on several occasions that the idea nearest and dearest to his heart when he was writing Anna Karenina was the "family idea." His novel, it could be argued, presents an expanded 900-page long explanation of what it takes to be a happy family. But who are the happy families of the novel? The marriage of the eponymous heroine herself to a much older high-ranking government official, Alexis Karenin, does not come about of her own choice, but is arranged for her by her wealthy aunt, who is her legal guardian. We are told that Karenin perceives their marriage to be a good one, but have our doubts as to Anna's experience of it, given her obsessive preoccupation with her son and her first instinctive reaction of recoiling from her husband after a short absence at the sight of his chilly artificiality and "gristly ears" (AK 103). When Anna meets Alexis Vronsky, a dashing officer, she falls in love with him and leaves her husband, scandalizing both him and herself and losing parental rights to her beloved son. Three lives are permanently shattered in the wake of her destructive love affair. Another unhappy family is that of Stephen Oblonsky, Anna's brother, and his wife, Dolly. Given to hedonism and dissipation, Stephen or Stiva, as he is called, is chronically and unrepentantly unfaithful to his wife and neglectful of his parental duties. Dolly, his long-suffering wife and mother of his six children, who stays with him, is both pitied and despised by her sister Kitty and brother-in-law Levin. Levin and Kitty's marriage is the best candidate for the appellation of a "happy family." Indeed we "catch" 
their relationship at the very beginning, follow it through courtship, wedding, first months together, and leave them soon after the birth of their first child, son Mitya. In more than one way, theirs is the "happy family" of the novel, which is contrasted to the unhealthy marriage of the Oblonsky, the failed marriage to the Karenin, and the ill-fated illegitimate relationship of Anna and Vronsky, resulting in a bastard child, infamy, loss of affection, and the final tragedy of Anna's suicide.

Tolstoy draws on the Biblical idea of marriage as symbolic of the original unity of man as a being constituted both by the male and female principle, a hearkening back to the time of the first partition or parturition of Eve from Adam's rib: "And Adam said, This is now bone of my bones, and flesh of my flesh; she shall be called Woman, because she was taken out of Man. Therefore shall a man leave his father and mother, and shall cleave unto his wife: and they shall be one flesh" (Gen. 2:23-24). In the Jewish mystical tradition, this idea becomes reflected and amplified as that of the Shekhinah. The word has several meanings. It signifies the feeling of God's presence, but it is also considered to be his female aspect, sometimes personified as Israel - both God's bride and daughter. Moreover, the Shekhinah is the soul of man. Originally created by God, all souls combine the male and female elements as they exist in the higher spheres. But as they journey down to Earth, the two parts separate, and only God knows where the two halves of the original soul reside. The man can only find his other half and complete himself by walking in the way of truth.

These metaphors of the original union and the separation of man are invoked throughout the novel. Thus, deeply moved by the liturgy of his traditional wedding ceremony, Levin contemplates the words of the prayer: "'Joinest them that were separate' 
- what a depth of meaning in those words, and how well they fit in with what I am feeling at this moment!" (AK 450). At the conclusion of the ceremony, the priest tells the couple to kiss: "Levin kissed her carefully on her smiling lips, offered his arm, and with a feeling of strange closeness led her out of the church. He could not believe it was all true, and only realized it when their surprised and timid glances met and felt they were already one" (AK 456). Three months into their marriage, as they are having their first big argument, Levin "for an instant ... was offended, but immediately knew he could not be offended with her because she was himself' (AK 479). Conversely, when Anna Karenina is receiving Dolly as her guest at her and Vronsky's fashionably appointed estate, she makes use of the metaphor of disjunction, as she breaks down in tears in front of her sister-in-law, talking about her forced separation from her son: "'Understand that I love equally, I think, and both more than myself - two beings: Serezha and Alexis.' . . 'I love those two beings only, and the one excludes the other! I cannot unite them, yet that is the one thing I desire"” (AK 636). What she means, however, is that she cannot unite herself: she herself is split between the two. In other words, the implacable and unnatural consequences of Anna and Vronsky's unholy union attain to the tragic level of the metaphysical sundering of Anna's subjectivity, while the church-sanctified marriage of Levin and Kitty, on the contrary, is figured in the novel in the valorized terms of wholesome synthesis: from two different beings they have become one complete whole.

Such backward-pulling nostalgic yearning for the state of original oneness that the dream of marital communion represents could be read anthropologically. The falling back from differentiation into undifferentiation, from individuation to pre-individuation is characterized by Hans Blumenberg as a "the longing to sink back ... to the level of 
[man's] impotence, into archaic resignation, ... the desire to return home to the archaic irresponsibility of simple surrender" (WM 9). The interpretation that he attaches to this desire to sink back is a surrender to the "absolutism of reality." Such is a reaction of resignation experienced by an early hominid, who has left its native environment in the rainforest for the savanna and now faces the challenge of meeting his food needs in the ecological niche, for which he lacks adaptation. Blumenberg describes this phenomenon as "intentionality of consciousness without an object" fraught with anxiety, which expresses "the pure state of indefinite anticipation" (WM 4). I would like to divorce this notion from a specific historical moment and interpret it in more general philosophicalanthropological terms, connecting it to my preceding argument about existential anxiety implicated in the "why-question." According to Blumenberg, people learn to cope with the catastrophic nature of their environment by noticing regularities, extrapolating, developing abstract concepts - the process that gradually leads to theory as "the better adapted mode of mastering the episodic tremenda of recurring world events" (WM 26). By classifying experimental knowledge and learning to make predictions, theory seeks to relieve the burden of catastrophic "episodicity." It searches for methods of breaking down complex phenomena of the natural world, of isolating objects in specific ways that would induce repeatable behavior and allow for the staging of reproducible experiments which lead to developing practices and procedures that guarantee predictable results enabling what Cartwright would call the creation of nomological machines.

In the realm of the physical world, nomological machines are generally welcomed (albeit not without reservations) as a manifestation of technological progress. In the social sciences and the humanities, they, however, present a problem that gives rise to a 
certain paradox. What is desirable about procedural knowledge in general is that it works to assuage the anxiety of being surrounded by threatening undifferentiated world by equipping the human with the capacity to anticipate "the recurring tremenda" and prepare for them. Another way of putting this is to say that by liberating the human from the paralysis of unspecified fears, procedural knowledge increases personal freedom. Understanding the world in terms of governing laws and principles sets man free from being rendered helpless by anxieties and uncertainties, arming him with foresight, and allowing him to focus his energies on planning a specific course of action. This thinking can also claim validity in being applied to a more general sphere of human knowledge the point I developed in great detail in Chapter II and will briefly repeat. Namely, on the one hand, representing man as the object of knowledge and building a nomological machine that models human behavior would be something desirable, as it would provide one with the same freedom-enhancing advantages as those just mentioned. When we, on the other hand, shift the representation from man as an object to man as a subject, when in place of "the Other" we substitute "I," we no longer wish to think of ourselves as nomological machines, as the same theoretical understanding that empowers us in dealing with our fellow man deprives us, paradoxically, of our own freedom of choice, causing us to become unfree. As a result, we both strive to systematize and construct procedural knowledge, viewing it as a liberating activity, and, at the same time, resist it as something fundamentally constraining. (Herein, I believe, lies one of the reasons for the humanities' ambivalence toward theoretical thinking).

This paradox of freedom manifests itself in the conflicting way we deal with ethics. According to one tradition, we are to act in accordance with a number of moral 
rules. From the Old Testament perspective, these rules are stipulated in the codex of the Mosaic law. The corresponding secular attitude understands ethical principles to be part of "natural law," comprising a number of logical propositions which postulate shared human goods and from which practical imperatives are derived. In contradistinction to this legalistic view, the opposing view acknowledges the problematic nature of confining moral behavior to a prescribed set of precepts, recognizing that a limited body of law may fail to give adequate counsel in every conceivable situation. There is always a possibility that a situation may always arise which calls for an exception from or extension of a rule. This is the view that is congenial to the Christian perspective on ethics. As Rufus Black sums up the philosophy of Christian moral realism: "the Christian does not simply follow laws that have been laid down; rather she formulates these laws as part of her ability to respond to situations in ways that allow her to expand her possibilities for human flourishing ... If obeying rules becomes an end in itself, rules will be a form of oppression because they will have lost their justifying purpose of directing a person toward her, and her community's, well-being" (CMR 222-223). However, having liberated themselves from the tyranny of the law, the adherents to the interpretative view find themselves on shaky ground when it comes to rationalizing their practical judgments. "When existing principles fail to offer ... insights [of wisdom], the Christian is called to turn to the Spirit for help in the task of discerning the right path to take" (CMR 223), and so all he has to fall back on is the authoritativeness of his interpretation. Kant, in his optimistic belief in reason, believed himself to have solved this conundrum. Postulating reason as a shared attribute of all rational beings allowed him to state that the morality of any action could be logically deduced by trying it out mentally 
as a universal moral law. It is this conception of the rational individual as the autonomous origin of moral principles that enabled him to reconcile the first and the second perspective: as someone who possesses intelligence, man freely recognizes himself as subject to the law of which he himself if the legislator. Kant's basic premise, however, of individual moral responsibility grounded in shared rationality has been variously criticized. He writes: "why should I subject myself as a rational being, and thereby all other beings endowed with reason, to [the universal law]? . . I must nevertheless take an interest in it and see how it comes about, for this 'ought' is properly a 'would' that is valid for every rational being provided reason is practical for him without hindrance" (FMM 76). This unproblematic conversion of an ought into a would is the crux of the problem. Pepita Haezrahi objects that although, according to Kant, "the same complex of circumstances and conditions which assures me of the certainty of my own freedom and moral responsibility, assures others of their freedom and their responsibility... no point in this argument necessarily implies an assurance for men of each other's freedom and moral capacity" (FMM 294). Kant, in other words, makes an unproven inductive assumption a foundation of moral action by transforming a "what is" (shared reason) into a "what ought to be" (mutual responsibility). As the grounding for ethics, this move necessarily fails because "of what is widely understood as Hume's contention that it is not possible to derive an 'ought' from an 'is"' (CMR 6), or an ethical imperative from a set of theoretical postulates. This confusion is illuminated by the ambiguity inherent in the notion of a law. The sense of necessity with which we endow theoretical premises owes to our concept of the Laws of Nature (for example, to explain a phenomenon, as shown above, is to demonstrate its inevitability according to some 
indispensable principle or assured regularity). But the idea of the Laws of Nature came fully into its own only after the Renaissance, retaining the connotation of social coercion or dictates of convention, and, for a while (long enough so that we can still recognize it in Kant), the boundary between the natural and the customary law remained blurred (an example previously mentioned is that of a rooster in the fifteenth-century Basel having been sentenced to burn at the stake for the recalcitrant "unnatural" act of laying an egg).

To some extent, this blurring still persists, underlying the explanatory productiveness of the narratives of moral transgression. The anthropology of these narratives has the function of "stabilizing" the meaning of moral injunctions by answering the question of "why should I obey this law?" with "because the punishment will be swift and certain (as this is the law)." Since we can offer no deductive proof of severe and unavoidable consequences of infraction, we amass the evidence inductively by a repeated telling of narratives that recount transgression. Re-telling of a narrative is a performative act that arrogates the predictive power to guarantee the moral law's certainty. In the case of Anna Karenina, an explanation of its ethical import is instigated by its epigraph, "Vengeance is mine; I will repay." In this particular phrasing, it is encountered in Romans 12:19 - "Dearly beloved, avenge not yourselves, but rather give place unto wrath: for it is written, Vengeance is mine; I will repay, saith the Lord" which is itself a quotation of a verse from the Old Testament, where in The Song of Moses (Deut 32:35), Moses says: "To me belongeth vengeance, and recompence; their foot shall slide in due time: for the day of their calamity is at hand, and the things that shall come upon them make haste." The contextual meanings clearly differ between the two quotations. In the latter case, the phrase functions as an unequivocal threat, a warning 
to the Israelites to resist the temptation of returning to their pagan ways. The etymology of the Hebrew word for law is traced to such verbs as "to shoot" or "to throw," both suggestive of the natural, inexorable causality of action. God forecloses the possibility of apostasy by promising: "I will heap mischiefs upon them; I will spend my arrows upon them" (Deut 32:23). And indeed, some Old testament narratives deal with the certainty of divine punishment. For example, the already mentioned Nadab and Abihu, Aaron's sons, are immediately killed after they offer an unsanctioned sacrifice (Lev 10:1-2), or a man who gathers sticks on the Sabbath is directly ordered by God to be killed (Num 15:3236). These and other instances make the punitive connotations of the injunction "to give place unto wrath" quite clear. In the New Testament version of the quotation, however, the rhetorical modality of the phrase is instead that of exhortation, not promised terror. Paul entreats his listeners not to take justice into their own hands. Preceding this verse are the verses where Paul instructs: "Bless them which persecute you: bless, and curse not" and "Recompense to no man evil for evil" (Rom 12:14, 17). The shift in meaning is underscored by the shift of moral paradigm: the abolition of the Mosaic Law by Christ's sacrifice. The New Testament believer is encouraged not to despair over his inability to live up to the impossibly high standard of the law, because the latter has been abrogated, through faith, by the gospel - "For sin shall have no dominion over you: for ye are not under the law, but under grace" (Rom 6:14) - and the abolishment of the law is an act of liberation: "Stand fast therefore in the liberty wherewith Christ hath made us free, and not be entangled again with the yoke of bondage" (Gal 5:1).

The moral transgression that is examined in Anna Karenina is that of an adultery committed by Anna with Vronsky. But in a broader sense, Tolstoy's "family idea" serves 
as a fertile thematic ground for investigating the violation of the tenth commandment, which Rene Girard understands to be the prohibition against mimetic desire (the imitation of one's neighbor's desire). Girard considers this desire to be the root of all violence, and the prohibition against it - the source of all other prohibitions: "Mimetic rivalries can become so intense that the rivals denigrate each other, steal the other's possessions, seduce the other's spouse, and, finally, they even go as far as murder ... If the Decalogue devotes its final commandment to prohibiting desire for whatever belongs to the neighbor, it is because it lucidly recognizes in that desire the key to the violence prohibited in the four commandments that precede it. If we ceased to desire the goods of our neighbor, we would never commit murder or adultery or theft or false witness" (SFLL 11-12).

Tolstoy's novel foregrounds mimetic contagion through all of its plot lines. Vronsky falls in love with Anna, because, with her reputation as a virtuous and brilliant society woman, she is perceived by him as unattainable and desirable by every other man. In her turn, what makes Vronsky more attractive in Anna's eyes, is the knowledge that Kitty is in love with him and that the Shcherbatskys expect an imminent proposal. What makes this situation self-reflexive and ironic is that in making a play for Vronsky, Anna chooses Kitty as her model after Kitty declares Anna to be her model, expressing her open admiration for the latter: “'How can you be bored at a ball?' 'Why can't I be bored at a ball?' asked Anna. Kitty saw that Anna knew the answer that would follow. 'Because you must always be the belle of the ball"' (AK 72). Predictably, once Anna succumbs to Vronsky's seduction, his interest in her starts to flag, only to be spurred once again by his realization that he might have lost her when, as a result of her serious illness, she briefly 
returns to her husband. When the breakdown of her marriage and, subsequently, her disgrace and banishment from society become final, he once more loses interest. The more indifferent Vronsky grows, the more Anna clings to him and the more desperate she becomes. Eventually, her situation appears untenable to her, which leads to her suicide. The adultery also affects Alexis Karenin in unexpected ways. The stigma of Anna's betrayal contaminates the way Karenin is viewed by society, rendering him a ridiculous figure in everybody's eyes: "he knew that for that reason - because his heart was rent in pieces - they would be pitiless toward him. He felt that people would destroy him, as dogs kill a tortured dog that is whining with pain" (AK 504). As a result of his loss of status, his up to now dizzying ascent up the career ladder is suddenly cut short. As he throws himself in his work, "writing a pamphlet on the new legal procedure," he does not yet know that this would be "the first of an innumerable series of unwanted pamphlets on every administrative department which it was his fate to write" (AK 513). Even the "good" couple is affected by mimetic contagion. Kitty, for instance, is awed by Vronsky’s good looks, money, high position, and influential connections - all those things that give him the fashionable status of Saint-Petersburg's gilded youth fellowship. These qualities make him more desirable in her eyes than plain-looking and undistinguished Levin, whose only distinction is the competent management of his and his brother's estate. Once she rejects Levin for the sake of Vronsky, only to have Vronsky reject her, Levin appears suddenly desirable to her again: "Her hopeless grief was really caused by the fact that Levin had proposed to her and that she had rejected him, and now that Vronsky had deceived her, she was prepared to love Levin and hate Vronsky" (AK 125). As for Levin - the most independently thinking and full of integrity 
character of the novel (widely considered to be Tolstoy's alter-ego) - even he is not immune to mimetic contagion, although its signs are more subtle in his case. For example, Levin harbors feelings of inferiority about being somewhat of a social misfit in lacking acceptance or respect within the social circles to which he belongs. His selfesteem is wounded because of not being taken seriously by the intellectual circle of his half-brother, philosopher Sergey Koznyshev. At the same time, his liberal friends, like Oblonsky and Sviyazhsky, upbraid him for his outmoded political opinions and the lack of engagement with liberal causes, while his brother Nikolai and his radical friends despise him for being a land owner and an oppressor of peasants. Neither does he belong to the fashionable society, despite the fact that he has enough money and stems from an old noble stock. There his agricultural pursuits tend to raise eyebrows, while his person causes general consternation by his "awkward manner" and his "strange and harsh criticisms" (AK 43). On the one hand, Levin himself chooses the position he is in, on the other, he feels like a failure when he reflects on the way he is perceived by others: "He was thirty-two, and while his former comrades were already colonels, aides-de-camp, Bank and Railway directors, or Heads of Government Boards like Oblonsky, he (he knew very well what others must think of him) was merely a country squire, spending his time breeding cows, shooting snipe, and erecting buildings - that is to say, a fellow without talent, who had come to no good and was only doing what in the opinion of Society good-for-nothing people always do" (AK 22). There is only one character in the entire novel, Mlle Varenka, who is depicted as someone entirely lacking the contagious type of mimetic desire and concerned solely with the welfare of others. Varenka's sincere Christianity and generous spirit of cooperation is contrasted starkly with the hypocritical 
Christianity of Mme Stahl, her foster mother. Significantly, however, Varenka, although beautiful and still young, is described by Tolstoy as a wholly asexual being. In several places, the narrators likens her to or associates her with mushrooms ${ }^{1}$, invoking a hermaphroditic imagery as a way of suggesting perhaps that only the original state of prelapsarian unity of the male and female aspect could be impervious to mimetic

\footnotetext{
${ }^{1}$ This point is made by Amy Mandelker in Framing Anna Karenina
} 
contagion.

By exploring the ramifications of competing mimetic desires, the plot of the novel centered around the "family idea" also probes deeper, serving as a paradigm of mimetic anthropology. The story of Adam and Eve - the first proto-family - already presents a problematization of mimetic desire before it is explicitly thematized in the rivalry of Cain and Abel. With the creation of Adam and Eve, the problematic of the "other One" comes into existence that, as Blumenberg would have it, exceeds the earlier and more primitive idea of the "Other" (which comes down, ultimately, to the menacing "absolutism of reality" that intransigently resists the submission to man's wishes) by becoming the next stage in conquering the hostile and incomprehensible environment through "a world exegesis... that involves man, who comes to know, in the story of the Other One, who comes to be known" (AK 22). This principally new mimetic problematic confronts man as he takes cognizance of the Other as the Other One and requires principally new measures of treatment. The Old Testament regulates mimetic desire through codification, offering to the pragmatic question of "what makes for a well-functioning family?" a specific answer in the form of 613 Mosaic laws and their elucidation by the Talmudic and Midrashic exegetes. These laws, which are meant to act as safeguards against what Rene Girard calls "mimetic snowballing," legislate in two blurred senses of the word, convention and nature, yoking together the "is" and the "ought." In the conventional sense, they operate in the prescriptive, procedural fashion of the nomological machine ("if you do this and this, your marriage will surely be happy"). Had it still possible for the man to cleave to the woman as the flesh of his flesh, had they been able to cooperate unproblematically as a "help meet" for each other to "dress and keep" the Garden of 
Eden, there would have been no subsequent story of the fall, no history of mimetic desire. But the nostalgic desire to "sink back ... into archaic resignation" is clearly unfulfillable, aiming at, as Blumenberg shrewdly suggests, the "pluperfect" - the past's past - the mythological time of human origin where all genetic explanations of human imperfection point to. All we are left with are nomological procedures that reduce the metaphysical "why" to a pragmatic "how." In its naturalizing sense, on the other hand, the Mosaic Law proclaims the unbending authority of the Divine Will to punish transgressors with the vengeance and indubitable certainty of the Laws of Nature. Yet there is always a suspicion that its self-proclaimed omnipotence might turn out to be just an empty threat. It is this possibility that Anna Karenina's subplot addresses. As other narratives of crimes and punishments, the story of Anna's transgression and her tragic end strives to normalize and naturalize something that cannot be empirically demonstrated - the moral law - but can only be re-asserted as an emphatic exercitive - "for in the day that thou eatest thereof thou shalt surely die" - or just as emphatically countermanded - "Ye shall not surely die" (Gen $2: 17 ; 3: 4)$. Once the moral law is transgressed, the mimetic nomological machine takes over, which, in Anna Karenina, leads to a mimetic escalation, triggering the chain of events that lead unstoppably to the final tragedy.

Although Vronsky pursues Anna nearly everywhere she goes and begs her to be his, she, for a while, resists his advances, but in the end, she succumbs to him. The instance of Anna and Vronsky's consummation is figured in the text symptomatically as an elision of dotted lines that represent the irreversible event that has just taken place. What has, in fact, happened is that Anna has made her choice by transgressing the moral law, and from this point on no further choice is possible. Vronsky in this scene is 
described as a murderer "looking at the body he has deprived of life. The body he has deprived of life was their love" (AK 148). "It's all over," Anna tells him, "I have nothing but you left" (AK 149). Anna's transgression swiftly invokes the vengeance of the jealous God of the Old Testament, who has ruthlessly dealt vengeance to Sodom and Gomorrah "because their sin is very grievous" (Gen 18:20). The irreparable nature of what has happened launches a narrative sequence of causes and effects that cannot be stopped, sidetracked, or reversed. Anna's disgrace and Vronsky's loss of affection are its inexorable outcome. As Anna Karenina contemplates her suicide, she tells herself: "Supposing ... I get divorced and become Vronsky's wife! What then? Will Kitty cease looking at me as she did this afternoon? No. Will Serezha stop asking and wondering about my two husbands? And between Vronsky and myself what new feeling can I invent? Is any kind - not of happiness even, but of absence of torture - possible? No! No!"' (AK 756). As if to underscore Anna's loss of control over her life, her last agonizing hours are depicted in a long metonymic sequence, discussed above, which represents her uninterrupted train of thought, whereby objects and street scenes that she observes steer her thinking along the rails of necessity. During her carriage ride, she sees sights and street scenes that only confirm her suspicions that the world is a pitiless place, and all its inhabitants are petty, resentful, envious, and ruthlessly competitive beings:

How glad [Dolly] would have been at my misfortune! . . [H]er chief feeling would have been joy that I am punished for the pleasures she has envied me. Kitty would have been still more pleased.... She is jealous of me and hates me, and she also despises me... . What are those churches, that ringing, and these lies for? Only to conceal the fact that we all hate each other, ... $[\mathrm{T}]$ he struggle for existence and hatred are the only things that unite people. (AK 752-4) 
This is a key moment of epiphany, in which the female protagonist suddenly understands the mimetic nature of human relationships. But what can this knowledge afford her at this point? Her insight comes too late, and the irreversible succession of events cannot be altered. "Suddenly ... she realized what she had to do. . . 'There!' she said to herself, looking at the shadow of the truck on the mingled sand and coal dust, ... 'There, into the very middle, and I shall punish him and escape from everybody and from myself!'” (AK 760). Her decision to escape is the only way she can assert her freedom: by extricating herself from the causal chain of necessity generated by mimetic escalation.

Anna Karenina's story line functions as an explanatory narrative of the "vengeful" meaning of the epigraph and an answer to the question of "why are some families unhappy?" The short answer is that mimetic desire causes Anna's tragedy and that her death serves as a compelling testimony to the mechanical nature of the Biblical Law. Yet the integrity of this explanation is somewhat compromised by various loose ends and inconsistencies that prevent us from a complete assurance that the Biblical Law succeeds in regulating mimetic desire. To begin with, justice seems to be meted out too capriciously to conform to this schema completely. Neither Stiva, with his profligate lifestyle and a string of mistresses, nor Anna's friend, Princess Betsy Tverskaya, who is equally open and cynical about her affairs, suffer any bad consequences. Another possible complication is the questionable status of Anna's suicide: after all, Anna kills herself at the end in an act of free will and is not killed, for instance, by the heavenly fire from above. By rejecting the Law, she finds herself imprisoned by the savagery of the even more confining world of mimetic law. But if this is Hell, she flees it by refusing the representation of herself as its trapped subject, and, in this last step of defiance, it could 
be claimed, regains her agency. These difficulties point to conceptual problems with constructing analogies, preventing us from telling a perfect transgression narrative, which might thus necessitate further re-tellings.

In contrast, Levin's subplot provides the paradigm for the way the New Testament deals with mimetic desire. Levin manifestly affirms his freedom by trying to sidestep the mimetic circle through his choice of the Scriptural path of Christian imitation - the path that stops all imitation by, as Girard maintains, choosing to imitate Jesus, who "invites us to imitate ... his own desire, the spirit that directs him toward the goal on which all intention is fixed: to resemble God the Father as much as possible" (SFLL 13). Here we are confronted with the complementary reading of the injunction of "Vengeance is mine. I will repay" that so confounded Luther. For Luther, the elusive verse of Paul in Romans 1:17 - "For therein is the righteousness of God revealed from faith to faith: as it is written, The just shall live by faith" - was experienced as acutely troubling. Thinking about it sent him into a profound crisis of faith as he contemplated the seeming frivolity of the idea of "the righteousness of God," understanding it as the inscrutable will of God, his propensity to impose justice without regard for the individual's piety and good works, saying to himself: “As if it isn't enough that we miserable sinners, lost for all eternity because of original sin, are oppressed by every kind of calamity through the Ten Commandments. Why does God heap sorrow upon sorrow through the gospel and through the gospel threatens us with his justice and wrath?" (qtd. in Wriedt, 89). After suffering through a period of mental anguish caused by conflictual meanings, Luther undergoes an experience of conversion, having re-interpreted the verse to mean that "the justice of God by which the just person lives by a gift of God, that is by faith. The 
meaning of this verse started to open up to me: The justice of God is revealed through the gospel but it is a passive justice by which the merciful God justifies us by faith, as it is written: 'The just person lives by faith."' (qtd. in Wriedt, 90). ${ }^{2}$ The shift in meaning that takes place for Luther between the punishing Old Testament interpretation of the avenging Creator and the Gospels understanding of God as a redeemer corresponds to the interpretative act itself. The mental and spiritual effort of meditating on the passage and explicating it contextually rewards him with the text's yielding a felicitous meaning that resonates with his inherent sense of right. ${ }^{3}$ Luther is thus liberated from the bondage to the letter of the law by the newly found power of interpretation, whose authority is underwritten by the coherence of signification made manifest in "one's heart": "For when Gentiles, which have not the law, do by nature the things contained in the law, these, having not the law, are a law unto themselves: which show the work of the law written in their hearts, their conscience also bearing witness ..." (Rom 2:14-15). As Victoria Silver notes in Imperfect Sense, he is at this moment delivered from the notion planted by the scholastic exegetes of the scripture that "word[s] [mean] in a void... as though their meaning were severely distinguished like the picture of bodies in space - single, discreet, and absolute" (IS 22).

\footnotetext{
${ }^{2}$ Although Eastern Orthodox Christianity does not subscribe to the doctrine of "justification by faith alone," Tolstoy's Christianity was rather idiosyncratic. He preached the gospel of "a living God," for which he was excommunicated. His religious views run close to the Protestant understanding of the "sola scriptura" principle. Russian philosopher, Nikolai Berdyaev, contends that "the Orthodox faith in Tolstoy's consciousness conflicted irreconcilably with his reason... Tolstoy remained 'an Enlightenment man'. All the mystical and sacramental side of Christianity, all the dogmas and mysteries of the Church evoked in him a stormy reaction of the Enlightenment reason" (par. 2).

${ }^{3}$ I am indebted to Victoria Silver's insight, equating Luther's hermeneutic act to an act of faith ("the shift of meaning is felt to be the virtual sensation of faith itself" (IS 21). I also rely on Paul Althaus's discussion of "the work of faith" in Luther ("Faith is an act of the will with which a man 'holds to' the word of promise" (TML 44).
} 
In a similar move, Levin arrogates to himself the power to interpret. During the conversation with Fedor, one of his peasants, he hears the latter praise another peasant, Platon, as someone who "lives for his soul and remembers God" (AK 788). This phrase catches him off guard and deeply moves him, spurring a religious conversion. He realizes that the meaning of life "is to live for God, for the soul." Moreover, he understands that he has, in fact, been living well, "but thought badly": "I looked for an answer to my question. But reason could not give me an answer - reason is incommensurable with the question. ... What I know, I know not by my reason but because it was given to me, revealed to me, and I know it in my heart by faith" (AK 790-793). In other words, what the New Testament reading of "righteousness" promotes is the solution to the dilemma of negotiating between the two kinds of unfreedom: being either constricted by the mechanistic exigencies of mimetic desire or coerced by the arbitrary despotism of the moral code. The shift in thinking re-appropriates freedom by extricating one from the vicious circle of mimetic behavior, thus rendering the Biblical law obsolete: "But now the righteousness of God without the law is manifested" (Rom 3:21). But the newly asserted freedom of interpretation grounded in such religious invisibilia as faith is, in itself, problematic. Rejecting the binding constraints of 613 commandments, the redemptive thinking lacks formal criteria on whose traditional authority it could fall back. Levin's final resolution reflects this difficulty. His gaining of the transformed understanding of what it means "to live for God" does nothing to alter his consciousness of the hereditary privilege. As he tells himself, he has already been living well: he could simply continue to abide by the same principles, while avoiding in his everyday actions the extremes of exploitation. 
As surely as one must pay one's debts, so surely was it necessary to keep the patrimony in such a state that when his son inherited it, he would thank his father, as Levin thanked his grandfather, for all that he had built and planted. . . . He knew that he must hire laborers as cheaply as possible; but that he must not take them in bondage for less that they were worth, ... He might sell straw to peasants in a time of shortage, though he felt sorry for them; . . . Felling trees must be punished as severely as possible, but if peasants let their cattle stray, he must not exact fines from them; . . He must lend money to Peter to liberate him from the usurers to whom he was paying ten percent a month; but he must neither reduce nor postpone payments of rent by the peasants who were in default. ... He must not pardon a laborer who went home at a busy time because his father had died ... but he could not neglect giving a monthly allowance to old domestic serfs who were of no use at all to him Levin knew, too, that on returning home the first thing he must do was to go to his wife ... and that the peasants who had been waiting for three hours to see him could wait a little longer; and that he knew that in spite of all the pleasure of hiving a swarm, he must forgo that pleasure, let the old beekeeper hive the swarm without him, and go to talk to the peasants who had found him at the apiary. Whether he was acting well or ill he did not know, ... Thinking about it led him into doubts and prevented him from seeing what he should and should not do. But when he did not think, but just lived, he unceasingly felt in his soul the presence of an infallible judge deciding which of the two possible actions was the better and which the worse; and as soon as he did what he should not have done, he immediately felt this. (AK 784-5)

Although Levin personifies the criteria of his judgment as "an infallible judge," it is hard not to question the arbitrariness of his principles and speculate that a different person or someone living in an era of different sensibilities would choose a different course of action in every particular case. In fact, the task of interpreting his situation contextually is fraught with such inordinate difficulties that thinking about it, as Levin recognizes, leads one into an abyss, and this is why he must resort to personification as a justification of his 
behavior. ${ }^{4}$ His resignation at the realization that "reason could not give him an answer" because "it is incommensurate with the question" is indicative of the predicament one finds oneself in when leaving behind a codified and culturally sanctioned set of principles. The situation is akin to the paralysis of facing the undifferentiated world all over again. This is what the Russian philosopher, Vasiliy Rozanov, had in mind when he wrote that "As everywhere in the Gospels, the trifle of 'turn the other cheek' rings hollow; it is an empty alleviation. In reality, Christ has burdened human life enormously, strewn it with 'thorns and thistles,' something loose and porous, something impossible. In fact, the justice of 'an eye for an eye' constitutes precisely that norm of earthly human existence, without which life would keel out of balance. It is exactly that clear, and simple, and eternal which characterizes the 'completeness' of God the Father and his everlasting foundation, that which closes the short with the short; instead of which we now have tears, hysterics, and sentimentality" (AOD 451). ${ }^{5}$

The impossible situation of positing oneself as the source and subject of representation opens up ground under one's feet that voids all narrative content. This is why Levin's story cannot really be told. Of the two subplots, it is Anna's narrative of

\footnotetext{
${ }^{4}$ Robert Althaus's point that receiving justification through faith involves a personal act of appropriation reflects this difficulty of contextualization: "The word of promise ... does not have authority in itself, as though it were a universally valid truth that demonstrates its own validity ... It does not convey a purely objective truth but rather is a word of acceptance and summons, of promise and command, which God personally addresses to me" (TML 44). But to receive God's word as a personal, not universal, truth, the believer, in a self-grounding act, must take a chance on the offered promise. To receive faith is thus, in a circular way, predicated on having faith.

${ }^{5}$ Pavel Gol'dshtein reads Tolstoy's novel in a Rozanovian way, arguing (incorrectly, in my opinion) that its message constitutes an outright rejection of Christian values and a return to the ethics of the Old Testament. A problematic status of his interpretation rests on the fact that he ignores that epigraph's provenance in the New Testament and attributes it directly to the Old Testament.
} 
transgression that, despite its inconsistencies, holds up, having enough structural integrity to be read as a meaningful explanation of "why some families are unhappy." Levin's, on the other hand, is not its symmetrical obverse of "why some families are happy." Firstly, because, an answer to this question is not a narrative but a procedural description of a nomological machine. Secondly, because we leave Levin and Kitty at the very threshold of their marriage, and what we are shown up to this point - not only their love and tenderness for each other, but also their first arguments, jealousies, and misunderstandings - does not set them apart from other newlyweds nor precludes the probability of things turning out badly at a later point (even if one resists reading this story autobiographically in reference to Tolstoy's own first happy and later disastrous marriage to Sophia Behrs). In keeping with this, even their match is shown to be accidental and not fated in some transcendent sense of being a union of two lost halves of one soul. Kitty "settles" for Levin as a replacement for Vronsky, while Levin's love for Kitty is shown to be a metonymic sequel of his love for the older Shcherbatskys sisters: first, Dolly, and then, Natalie. In a way, Levin's is a "story about nothing." We follow him through his first unsuccessful and then successful courting of Kitty, his failure to find meaningful civic engagement in the local rural administration, his attempt to re-organize agricultural practices on his estate in a both more efficient and ethical fashion (a fascinating subplot, in itself, that is suddenly dropped), his grief and anxiety at witnessing the death of his brother (an experience that throws him into the tailspin of depression), the birth of his first child, and, throughout all of this, his unrelenting and passionate search for the meaning of life. When this meaning is finally opened to him - "to live for God" - it does not throw any light on the preceding narrative, it is neither explanatory nor 
redemptive. Neither we nor Levin are any wiser at the end as to why some families are happy or whether his own family is bound for happiness. Nor does his final epiphany tie the random events of this subplot into an intelligible, cogent whole, accessible through an act of interpretation. On the contrary, his story line resists interpretation through aborted narrative strands, elisions, and actions based on narratively inscrutable motivation. Thus, we come across a casually dropped reference to Levin's attempted suicide, inserted almost as an afterthought and striking in light of his initial marital happiness: "And though he was a happy and healthy family man, Levin was several times so near a suicide that he hid a cord he had lest he should hang himself, and he feared to carry a gun lest he should shoot himself" (AK 783). And, very importantly, Levin's revelation does not lead to any decision - after all "he was living well," as he realized, and "recently even more unfalteringly than before" - although we are only told and not shown this, and although this statement is difficult to reconcile with his nearly attempted suicide (AK 783). He tells himself, therefore, that he will continue as he has always done: "I shall still get angry with Ivan the coachman, shall dispute in the same way, shall inopportunely express my thought; there will still be a wall between my soul's holy and holies and other people; even my wife I shall still blame for my own fears and shall repent of it” (811).

But for Levin himself, a monumental shift in attitude takes place when he resolves for himself the meaning of "living for God." As he explains to himself: "My whole life, independently of anything that may happen to me, is at every moment of it no longer meaningless as it was before, but has an unquestionable meaning of goodness with which I have the power to invest it" (AK 811). This private explanation, which empowers him, is neither communicable nor transmutable into an interpretable explanandum of the 
novel's first sentence. In the question of "why some families are happy while others are not," one can discern both a tinge of awe and anxiety in the face of life's diversity as well as a prompt for a successful recipe of a good marriage. Behind it is a desire to inhabit freely and navigate a world, that is to represent oneself as free. As a regularized, procedural know-how, the answer to the question of "why some families are happy" can only be implied by the narrative of "why some families are unhappy" - the narrative of the transgression of the law that can be told, because it records an unrepeatable, singular event. Its very narratability underlies the statement that every unhappy family is unique. But as a narrative, the answer to the question of "why some families are happy" cannot be told, because "the answer is incommensurate with the question." By dispensing with meaning-giving law, by arrogating to himself "the power to invest his life with meaning," Levin places himself in the void of the pluperfect. Facing the task of grounding his own system of significance, he finds himself before the moment of the world exegesis, at the threshold of being able to tell the story of his alter ego as the "Other One who comes to be known." 